\title{
A ÉTICA POLÍTICA NA PRIMEIRA REPÚBLICA NA FICÇÃO DE LIMA BARRETO
}

MESQUITA, Sergio Luiz Monteiro

Qualquer estudo sobre a obra do escritor Lima Barreto muito dificilmente poderia deixar de tocar na questão de sua crítica social contundente e inquietante em relação ao Brasil que conheceu em seu tempo e que, em linhas gerais, quase não difere do Brasil deste início do século XXI. Dentro desta crítica, muita vez efetuada sob a forma de alegoria e sátira, comparece o comentário e a análise dos fatos políticos contemporâneos à sua atividade literária; comentário e análise necessariamente indissociáveis de uma avaliação ética, manifesta ou implícita. Diversos autores têm analisado o conteúdo da crítica barretiana, entre outras coisas, às práticas políticas brasileiras e ao caráter dos dirigentes nacionais, incluindo as motivações pessoais, éticas e estéticas de Lima na produção desta crítica. Intelectual atento à vida de sua sociedade, Lima Barreto interessouse pelo desenrolar dos eventos políticos, no período histórico em que viveu, a Primeira República, também conhecida como República Velha (1889-1930). Deixou registradas as suas impressões sobre eles, em diversas modalidades de escrita, às vezes abordando repetidamente os mesmos fatos e situações, sob luzes diferentes.

Objetivamos no presente trabalho, a nível geral, abordar a postura de Lima Barreto sobre a questão da ética na política oficial do Brasil durante o primeiro período do regime republicano, lembrando que, morto o escritor em 1922, não chegou a abranger com sua observação todo o período. De modo específico, entre os momentos da história dessa república inicial do Brasil, comentados ou apresentados pela escrita de Lima Barreto, focamos o governo do presidente Hermes da Fonseca (1910-1918). Este período é apresentado ficcionalmente em vários escritos do autor; recordamos principalmente as novelas "Numa e a ninfa" e "As aventuras do 
Doutor Bogóloff", e os "Contos Argelinos". Os textos básicos sobre os quais trabalharemos serão os chamados "Contos Argelinos". A citação que fizermos de outras obras do autor atenderá basicamente ao objetivo de ilustrar algumas observações sobre a época, a sociedade e o regime, que julgamos necessário fazer, a fim de uma melhor abordagem do nosso objeto específico.

Quanto à escolha dos "Contos Argelinos" para basear nossas observações sobre esta questão ética, vale colocar algumas palavras. Há alguns anos atrás, lendo uma coletânea de contos de autoria de Lima Barreto, deparamo-nos com um conjunto destacado sob o título "Contos Argelinos", formando uma coleção de pequenas sátiras políticas (LIMA BARRETO: 1990, pp.231-258). Foi justamente seu tom alegórico que nos chamou a atenção e induziu-nos a relacionar as indicações do texto com fatos e pessoas da realidade social e política brasileira da época do autor. Assim, fomos identificando a cada parágrafo personagens e situações do governo conturbado do marechal Hermes da Fonseca. Mais tarde, tivemos conhecimento do lançamento, em 2010, de um livro do pesquisador de literatura Mauro Rosso, apresentando de forma organizada e comentando os "contos argelinos" e outros textos recuperados de Lima Barreto, inclusive textos de teatro (ROSSO: 2010, pp.71-118). Nessa obra, vimos que Rosso praticou exercício semelhante de identificação de personagens e situações, o que nos foi bastante útil para corroborar algumas hipóteses nossas neste exercício e nos dar preciosas indicações.

Relacionando esses textos a outros do autor em que comparecem referências a esta quadra da era republicana, tivemos o interesse em observar e analisar como a ficção barretiana tratava fatos da história da Primeira República deste teor, ou seja, fatos cuja dramaticidade manifestou-se de forma mais intensa, seja pelos episódios de violência que envolveram, seja pelos contextos de crise política nos quais tiveram lugar. Também refletiremos sobre sua postura em relação a este tipo de atos quando cometidos por 
governos conduzidos por mandatários militares. Lembremos os conflitos que marcaram o governo de Floriano Peixoto, cuja violência e os seus componentes ideológicos e sociais receberam uma descrição magistral em Triste fim de Policarpo Quaresma, tendo como ápice dramático a crueza dos confrontos e da repressão à Revolta da Armada. O governo de Hermes, década e meia depois, teve em comum com o de Floriano a passagem ao primeiro plano das ações dos setores militares ligados a cada um desses dois presidentes. Junto a isto, embora não se possa classificar o caráter geral das administrações de presidentes civis da época como propriamente pacífico, estes dois governos de presidentes militares chamam a atenção pelo extenso recurso às armas de que lançaram mão, a fim de tratarem de seus problemas, sem esquecer da fraude e da intimidação, por sinal uma constante no modus operandi das práticas institucionais do período.

Propomo-nos também a refletir sobre a intencionalidade de Lima Barreto em relação ao efeito que ele pretendia alcançar, mediante a narrativa em forma alegórica de algumas das peripécias principais do governo do marechal Hermes da Fonseca; forma bem diferente da que utilizou para relatar o calvário do patriotismo do major Quaresma, sob o governo de Floriano. Ligados a isso, os possíveis motivos para que acontecimentos da gestão Hermes fossem apresentados sob forma alegórica. Uma possível explicação consistiria em que a prudência teria pautado as páginas escritas por Lima Barreto nos "Contos Argelinos", fazendo-o evitar alusões diretas aos principais responsáveis pelos fatos que apresentou. Eram membros da camada dirigente, os quais, mesmo com o encerramento do mandato em que os fatos se deram, ainda ocupavam posições de poder dentro do sistema político, o que os tornava obviamente elementos temíveis. Os contos em questão que tratam especificamente destes acontecimentos foram publicados entre maio e agosto de 1915, ano seguinte à saída de Hermes da presidência, 
formando uma série na revista Careta, quando a lembrança dos acontecidos estava obviamente fresca, e passível de incomodar. Acresce o fato de que, sendo os envolvidos nesses atos de desmando e violência, na maioria, militares, alguma represália advinda deles encontraria ainda mais vulnerável o humilde amanuense da Secretaria da Guerra que ousava criticá-los, e suas ações. Daí, ficaria explicado o revestimento alegórico que Lima Barreto imprimiu às narrações desses eventos tempestuosos da presidência Hermes da Fonseca. É uma das questões que a leitura desses contos suscita.

Outra questão, cujo caráter geral envolve as anteriores, e que os liga a outros escritos do autor referentes à fase do mandato de Hermes, constitui-se em torno da caracterização do tipo de regime republicano brasileiro e do quanto à situação institucional influía nas posturas éticas - e aéticas - dos seus cidadãos, em especial dos dirigentes.

O panorama brasileiro do período mediado pela passagem do século apresentava um novo regime político, cujas bases ainda eram frágeis e que buscava se consolidar. As dificuldades dos fundadores da República de impor a nova ordem evidenciavam-se nas lutas acirradas entre os grupos dirigentes e nos movimentos de protesto e contestação partidos de vários setores da sociedade, mormente os menos favorecidos do ponto de vista social. O interrompido governo do marechal Deodoro, a ditadura de Floriano e os primeiros mandatos de governo civil que se lhes seguiram transcorreram num esforço de consolidação do regime, cuja dificuldade mostra, entre outras coisas, a carência de bases sociais fortes. A camada dirigente republicana, à falta de mecanismos institucionais mais sólidos, apelava com desenvoltura para recursos escusos de controle sociopolítico, como a utilização de elementos ligados ao crime e à marginalidade, mantendo assim a ordem com componentes da desordem. Numa tal ambiência, os limites éticos de comportamento político afrouxavamse e padeciam de uma enorme imprecisão. A República não 
entusiasmava a imensa maioria da população, na qual avultavam as classes subalternas, as quais demonstravam por suas atitudes a contrariedade por não terem seus interesses coletivos levados em consideração pelos governos, e revelavam a constatação, acertada, de estarem excluídos do jogo político (CARVALHO: 1987, pp.161164). Foi este quadro que Lima Barreto conheceu durante sua atividade de homem de jornal, cronista, contista e romancista.

A condução dos negócios públicos por uma elite governante avessa aos interesses populares e composta, na quase totalidade, de indivíduos e grupos, unidos em solidariedade de classe, apenas para a manutenção de uma ordem que os favorecia particularmente, tornou-se alvo da escrita questionadora do intelectual, identificado com as classes subalternas e uma ética de viés coletivo. Através do depoimento fictício de um de seus personagens, o Dr. Bogoloff, golpista russo radicado no Brasil e habitué dos meios políticos nacionais, Lima Barreto explicita em linhas gerais o teor dessa prática de poder: "A política, por esse tempo, mais do que nunca, constituía um jogo de interesses estritamente pecuniários, representados pelos proventos dos cargos e o que se arranja com auxílio deles." (LIMA BARRETO: 2001, pp.130-1). No mesmo sentido, o cronista-narrador de "Os Bruzundangas", descrevendo a discussão política na sociedade da República da Bruzundanga (o Brasil), assevera: "A política não é aí uma grande cogitação de guiar os nossos destinos; porém, uma vulgar especulação de cargos e propinas" (LIMA BARRETO: 1998, p.72).

Manifestações análogas dessa opinião, extremamente desfavorável sobre o regime republicano, tal como se instalara no país, estão presentes em diversas passagens da produção do escritor, ao longo dos anos, deixando fora de dúvida que tal ideia constituía uma das linhas-mestras da mesma produção, e testemunhando a constância e a solidez que ela adquirira no espírito de seu autor. Nesse sentido, conforme frisaram diversos outros autores, o interesse 
no enriquecimento particular, a corrupção e a venalidade se encaixam na cultura do patrimonialismo, que se caracteriza pela frouxidão de limites entre o que seria público e aquilo que constituiria a esfera do privado, eis que os agentes da ordem política tendem a considerar, em última análise, o Estado como uma instância que pode ser apropriada por particulares e utilizada para seus fins. Nesta perspectiva entram o uso do monopólio legal da força, conferido pelo Estado a esses agentes, e o prestígio da autoridade, para a prática de atos duvidosos do ponto de vista ético, ainda que supostamente sob a cobertura da lei. O desenrolar do governo Hermes, inclusive em suas origens, forneceu fartos exemplos que Lima Barreto aproveitou para estabelecer a confrontação entre a realidade dos fatos e valores éticos, considerados minimamente necessários para a existência de uma sociedade equilibrada.

A presença do marechal Hermes na sequência dos presidentes da chamada República Velha foi um caso algo destoante, em relação ao critérios de escolha dos candidatos à presidência, que vigoravam nessa época. A "política do café com leite", que as elites hegemônicas de São Paulo e Minas Gerais impunham, para orientar a escolha dos futuros presidentes da República, fazia com que se alternassem na presidência políticos indicados por um desses estados e políticos apontados pelo outro. É claro que este esquema, para se realizar, necessitava do comum acordo dessas duas elites, mesmo à revelia dos interesses das demais elites estaduais. Estas últimas, em geral fracas e dependentes do governo federal, não podendo se opor com eficácia aos desígnios dos estados mais poderosos, buscavam retirar do esquema o que era possível em termos de benefícios através de barganhas e favores.

A indicação do marechal sobrinho do ex-presidente Deodoro resultou de um impasse entre as lideranças com poder decisório na sucessão presidencial. O presidente Afonso Pena, mineiro, ele mesmo eleito em função do "café com leite", após tentar infringir a 
combinação dessa "média" oligárquica, indicando por sua própria conta um sucessor, entrou em séria complicação política, a qual teve, por desfecho inesperado, a sua própria morte durante o mandato sem que houvesse candidato oficial definido. Na crise que se seguiu à morte do presidente, enquanto o vice Nilo Peçanha concluía o mandato e procedia à realização da eleição para o próximo quatriênio, os nomes sugeridos para a sucessão esbarravam em obstáculos, inclusive o de Hermes, ex-ministro da Guerra do falecido presidente. No entanto, ele superou os seus concorrentes à candidatura oficial. As razões de sua vitória preliminar na posição de candidato oficial e da posterior ascensão à cadeira presidencial derivaram de dois fatores: a dificuldade, não vencida pelas oligarquias estaduais mais importantes, de se compor em torno de um nome, e a atuação do senador Pinheiro Machado e aliados. Eles viam na entrada do poderoso militar na disputa presidencial um meio de sacudir o esquema de controle do Executivo federal por São Paulo e Minas, em favor de oligarquias menos poderosas, como era o caso do Rio Grande do Sul, estado representado pelo senador. À época, embora não participasse do esquema hegemônico a nível federal, Pinheiro Machado era considerado como o político mais influente do país, verdadeiro "diretor da política nacional". Incapaz de obter uma hegemonia isolada da oligarquia de seu estado, o político gaúcho seguia a estratégia de tentar reunir em torno de si as oligarquias descontentes com a política do "café com leite", sem abrir mão de outros apoios. Como o das lideranças do Exército, com muitas das quais mantinha um bom relacionamento. Nisto, seguia a tendência da oligarquia situacionista do Rio Grande do Sul à qual pertencia chefiada por Júlio de Castilhos e em seguida Borges de Medeiros, unindo forças com a Arma desde os tempos da ditadura de Floriano.

Desde os tempos do Império, o Exército via desenvolver-se em suas fileiras um sentimento de classe e a vontade de participação mais ativa na política brasileira, que se consubstanciaram em 
conflitos com autoridades civis, julgadas hostis e desrespeitosas para com a Força. Os estimuladores e condutores desse processo de afirmação acabaram por envolver as tropas numa atitude de animosidade frente ao regime imperial, habilmente capitalizado pelo movimento republicano, do que resultou a intervenção militar que proclamou a República, como se sabe. Num clima ideológico onde circulavam e ganhavam força as idéias do positivismo, e no qual admirava-se o exemplo de republicanismo das nações da América, elaborou-se a representação da ação política levada a cabo pelos militares como a atitude do "cidadão fardado", figura ideológica justificadora da tendência intervencionista do soldado, no tocante aos rumos da vida política nacional. Esse "militarismo", concentrado nas lideranças do Exército, ao consubstanciar-se em comando político, atraía a simpatia de setores republicanos postos à margem do poder pelos desígnios das oligarquias tradicionais dominantes, enquanto estas, agrupadas mesmo desigualmente em torno da política do "café com leite" e dos conchavos das "política dos governadores", tendiam a eternizar os seus representantes no controle dos governos federal e estaduais. O "jacobinismo" de grupos e indivíduos civis, principalmente urbanos, refletiu o entusiasmo de alguns dos setores a que nos referimos, apoiando a intervenção militar para a manutenção do regime, realizada pelo governo militarista de Floriano. Todavia, desde a posse do primeiro presidente civil, a influência militar na política sofrera um refluxo. A classe dos latifundiários, liderada pela cafeicultura, assumia através de seus representantes o leme do Estado. A crise sucessória do final do governo Pena constituiu, então, uma oportunidade de recuperação desse protagonismo do Exército.

Perante a possibilidade de surgir um governo encabeçado por elementos do Exército, dos que cercariam o futuro presidente, houve reação contrária nos meios oficiais. Rui Barbosa incluía-se entre os políticos cotados para ser o candidato oficial e, participando do 
debate nas instâncias decisórias, levantou-se decidido contra o crescimento do nome do ex-ministro da Guerra. Assumindo a função de porta-voz dos descontentes com o advento do "militarismo", o advogado baiano não se conformou com a decisão das instâncias federais de apoiar o sobrinho de Deodoro para a sucessão de Pena, rebatendo com o lançamento de sua própria candidatura para a disputa eleitoral. Mais do que uma competição renhida, diferindo da maioria das campanhas presidenciais da época, em que o peso da ajuda oficial, a fraude e a intimidação eram decisivas para uma tranquila vitória dos candidatos oficiais, a disputa que definiu nas urnas e no reconhecimento do Congresso o sucessor de Afonso Pena foi um acontecimento sem precedentes. Foi a primeira campanha eleitoral para a presidência digna desse nome; despertou um genuíno interesse pela escolha do presidente e do vice-presidente, fora dos círculos do poder, conseguindo entusiasmar multidões, principalmente nas áreas urbanas. A "Campanha Civilista", como foi crismada, apelou à opinião pública, com manifestações voltadas para a população e a criação de um clima de debate através do país. 0 tribuno que animava a oposição, dessa vez, era uma voz autorizada e no auge de seu prestígio. Junto com Rui, comandava a campanha Albuquerque Lins, presidente de São Paulo e nesse momento seu companheiro de chapa. No apoio a Rui, três estados: além do estado bandeirante, a Bahia, área de influência do candidato oposicionista, e o Rio de Janeiro. A população envolvida no debate nacional pôde ter a impressão de que the era possível, formando maioria, escolher o vencedor. Contudo, seguindo a praxe do sistema, venceram Hermes da Fonseca e Venceslau Brás, tanto nas eleições quanto no reconhecimento dos poderes. Rui ainda tentou obter a impugnação do marechal, sem êxito. Contagiado de alguma forma pelo esforço civilista, Lima Barreto apoiou Rui no pleito, incluindo-se entre os muitos cidadãos que lhe declararam apoio. Apoio menos por simpatia a Rui do que por aversão ao militarismo, que ameaçava entronizar-se 
com a chegada de Hermes ao posto de supremo mandatário (BARBOSA: 1981, pp.187-188).

Com efeito, o temor dos civilistas e seus simpatizantes, de ver retornar o arbítrio e a violência militar, não deixou de se materializar na gestão do marechal Hermes. A animosidade e a agitação que haviam caracterizado a recente campanha eleitoral tinham contribuído para evidenciar com mais contundência a fragilidade política da posição do marechal, tanto como candidato, quanto como presidente. Uma providência para sanar esse problema foi a formação de um novo partido para apoiá-lo durante a gestão, o Partido Republicano Conservador, iniciativa de Pinheiro Machado. No entanto, apesar de medidas nesse sentido, Hermes e seus colaboradores mais íntimos inclinaram-se por atitudes mais drásticas para debelar as oposições e assegurar o controle do país. Não esqueçamos que, nem bem tomara posse, ainda no final de 1910, explodira a rebelião dos marinheiros contra a prática dos castigos corporais na Marinha de Guerra, conhecida como Revolta da Chibata, episódio que abalou bastante o prestígio do governo federal. Embora a candidatura do marechal tivesse sido apoiada por boa parte das oligarquias dominantes nos estados do norte e nordeste, atreladas à aliança com o bloco de Pinheiro Machado, o governo central passou a estimular ou ao menos tolerar tentativas de substituição dessas oligarquias promovidas por integrantes de seu círculo de colaboradores, no geral militares. Decisivo para a adoção de tal procedimento foi o fato de que a ascensão de Hermes representou a elevação de diversos de seus familiares e amigos pessoais para posições políticas de relevo. Ao mesmo tempo, excitou a cobiça de vários para a conquista de postos ainda mais importantes. Entre estes estavam membros de seu ministério, que se dispuseram a conquistar governos estaduais, utilizando a simpatia e os favores do presidente. O grande instrumento dessas tentativas de subverter o status quo dentro de vários estados foi o Exército, em cujo interior circulava um discurso 
que conferia aos militares a missão de remover as oligarquias ineptas e opressoras, a fim de "salvar" os estados que estas dominavam discricionariamente.

Iniciava-se sob o governo Hermes a política das "salvações", cujo método pode ser resumido no seguinte: o lançamento de uma candidatura concorrente à da situação de cada estado, normalmente de um oficial do Exército, em vista da eleição para presidente (governador); processo que desencadeava durante a campanha um clima de agitação e violência dentro do estado em questão. O desfecho seria a deposição da oligarquia dominante, com a eleição do candidato oposto através do simples sufrágio, ou a sua imposição ao estado por meio da intervenção de tropas federais e seus aliados. Essas "salvações" deveriam atingir a maior parte dos estados brasileiros, e várias só deixaram de ser levadas a cabo devido aos esforços de Pinheiro Machado e dos grandes estados também ameaçados. De fato, no grupo palaciano de familiares, amigos e assessores do marechal e presidente havia interesse em combater a proeminência do político gaúcho, cujo poder agregava o apoio umbilical do governo do Rio Grande do Sul, a aliança com boa parte das oligarquias nortistas e nordestinas e com outros grupos influentes na política federal. Para evitar que várias das pretendidas "salvações" se efetivassem, agravando o prejuízo que já sofria com a queda de preciosos aliados, Pinheiro Machado teve que se empenhar em negociações. Por seu lado, os estados mais poderosos da federação, menos dependentes dos favores ou dos furores federais, demoveram o governo central de seus desígnios de intervenção. São Paulo, após dispor-se à resistência armada, obteve uma negociação e colocou à testa de seu governo um nome respeitado nacionalmente, Rodrigues Alves, ex-presidente da República. Já o Rio Grande do Sul apoiou-se, como de costume, na conhecida força de suas milícias, dado que desestimulou qualquer intervenção federal, não só naquele 
momento, como durante toda a época de predomínio oligárquico no país.

Os acontecimentos de maior violência física e terror militar referidos nas narrativas dos "Contos Argelinos" são alegorias das "salvações", promovidas, como dissemos, pelos partidários e aliados do marechal-presidente em vários estados, objetivando remover as situações estaduais incômodas ao governo federal, ou conquistar os domínios que atraíam a ambição de alguns dos principais colaboradores de Hermes. No entanto, embora tivessem ocorrido várias, apenas duas delas são referidas, a de Pernambuco e a da Bahia. Nos contos, o Brasil ganha o pseudônimo de Al-Patak, império com ares de Argélia ou qualquer Estado muçulmano, governado pelo sultão Al-Dhudut (Hermes), usurpador do trono que ocupava, e composto de principados vassalos (os estados). Nele se sucedem abusos de poder, traições, casos de corrupção e ações violentas. Tais atos são praticados não apenas pelos servidores diretos do sultão, ele mesmo perpetrador de uma sequência de desmandos e indignidades, mas também por autoridades e elites dos principados.

Lima Barreto começa dizendo que o sultão usurpara o trono que ocupava da maneira mais inconcebível. A respeito disto, Rosso lembra que a crítica do autor a Hermes da Fonseca começava pela forma como fora proclamada a República, que se revestira de um caráter de usurpação (ROSSO: 2010, p.83). Neste caso, parece-nos que a referência do conto volta-se mais para a própria eleição desse marechal, após uma campanha em que a simpatia popular parecera ter pendido para o lado de seu adversário, Rui Barbosa, sendo criada até a expectativa de vitória da oposição. A "Campanha Civilista" contara com amplas simpatias, inclusive obtendo de Lima manifestações de apoio. A derrota do candidato civil no pleito foi alvo de denúncias do político baiano aos já costumeiros processos viciados de organização e contagem dos sufrágios - que ele mesmo, aliás, de forma alguma ignorava, veterano partícipe da política oficial que era. 
Como já dissemos, os termos em que a chapa hermista venceu, trazendo para a posse severas acusações de fraude e intimidação do eleitorado, foi outro dos fatores de enfraquecimento da autoridade do novo presidente, cujo alter-ego ficcional, Al-Dhudut, segundo a narrativa, era consciente de sua impopularidade e da baixa conta em que o povo o tinha.

O indigno sultão multiplicava os seus desatinos e crueldades, e enquanto desdenhava a opinião popular, satisfazia-se com as bajulações de seus servidores e as deferências dos mandatários estrangeiros. Cumulava seus amigos e parentes de favores e os nomeava para cargos na administração e nos principados vassalos. Como o povo de Al-Patak não reagia contra ele, o déspota vivia sossegado, "tramando violências com o seu vizir Pkent-Phin, um homem cruel e violento, que fora na sua mocidade criador e castrador de cavalos" (LIMA BARRETO: 1990, p.232). Informando que, num Estado muçulmano, a palavra vizir designa um alto funcionário responsável pela administração política e militar, Rosso conclui que Pkent-Phin refere-se ao ministro da Guerra do início da gestão Hermes, general Dantas Barreto (ROSSO: 2010, p.84), mais adiante o chefe da "salvação" de Pernambuco. Todavia, observando as características do personagem, identificamos nele o próprio Pinheiro Machado. Sendo uma espécie de eminência parda do governo, bem poderia ser caracterizado como "vizir" de Hermes da Fonseca, ainda mais que a parte final do nome de "seu" personagem parece insinuar "Pinheiro". Acresce que o político gaúcho, que as biografias apontam também como pecuarista no Rio Grande do Sul, tem lugar em outros textos da ficção de Lima Barreto com características de um homem afeito a lidar tanto com gado como com gente, a ponto de não encontrar muita diferença entre irracionais e seres humanos, como quando aparece como o senador Sofonias, "o diretor da política nacional", de "Aventuras do Dr. Bogoloff" (LIMA BARRETO: 2001a, pp.132-133). Já Dantas Barreto pode ser 
identificado como o "agha" (comandante militar), que figura mais adiante, no conto "O juramento", fazendo sua própria usurpação do poder de um principado vassalo de Al-Patak.

Logo que Abu-Al-Dhudut se apossou do trono de Al-Patak, todos os seus companheiros e amigos quiseram também fazer 0 mesmo nos reinos vassalos, embora muitos dos soberanos destes tivessem ajudado Abu na sua usurpação.

O primeiro agha (ministro da Guerra) ansiava por ocupar o governo do canato de Al Súgar, região rica e vasta, que até ali era governada pelo Cã Ross Al-Xeiroso. Este príncipe não se incomodava muito com a administração dos seus domínios e vivia em passeios e festas, fora da sua capital. (LIMA BARRETO, 1990, p.237.)

Al Súgar (Pernambuco) foi alvo da ambição do General Dantas Barreto, ministro da Guerra de Hermes, o qual logo empenhou-se em obter o cargo de presidente desse estado. Este era governado pela oligarquia liderada por Rosa e Silva (Ross Al-Xeiroso), chefe mais prestigiado, não apenas de Pernambuco mas do Nordeste inteiro, exvice-presidente da República, cujos hábitos correspondiam ao do personagem que o representa nos contos. Renunciando ao cargo de ministro, o general embarcou para o estado com uma comitiva de correligionários. Seus atos seguiram o método já descrito das "salvações", que em Pernambuco provocou uma campanha eleitoral repleta de incidentes violentos, envolvendo autoridades estaduais, tropas do Exército, capangas dos oligarcas e povo. Distúrbios que terminaram pelo reconhecimento do general como novo governador, a 18 de dezembro de 1911 (SILVA: 1998, pp.149-151).

A outra salvação narrada nos contos em questão foi a que trouxe a Bahia para as mãos de J. J. Seabra, ministro da Viação e Obras Públicas. O clima de tensão e ameaça sobre a capital baiana, manifesta a vontade de Seabra de disputar o governo local, precedeu à explosão dos ânimos, nos primeiros dias de 1912. A artilharia da 
tropa de intervenção federal atirou sobre a cidade, provocando a renúncia do governador em exercício, que, mesmo retornando, não logrou reassumir o controle do estado. Renunciou pela segunda vez, e Seabra acabou por se eleger governador de seu estado natal (SILVA: 1998, pp.153-156). Sobre o caso da conquista do canato de Hbaya (Bahia), Lima Barreto cita, entre outros, um fato que, no conto, identifica claramente a "salvação" hermista deste estado nordestino. Relata que o canato resistira aos desígnios de controle do governo central, diferentemente do que se esperaria, por ser Hbaya dividido em facções e possuir uma população menos austera e orgulhosa que a de Al-Bandeirah (São Paulo), que se tornara o núcleo da resistência ao "sultão". Foi o que se deu realmente com a "salvação" na Bahia, onde, com efeito, o governo local enfrentou armado as forças federais. E o fato marcante e comprovador da referência ao caso, citado com vestimentas de fábula por Lima Barreto, é o fato do bombardeio sofrido pela cidade de Salvador neste episódio: "A cousa foi dolorosa e triste, pois a capital de Hbaya foi bombardeada, as suas casas incendiadas, o príncipe reinante andou daqui para ali, fugindo (...)" (LIMA BARRETO: 1990, p.244).

Malgrado os relatos da truculência militar nas conquistas dos "canatos" efetuadas pelos prepostos do sultão, percebemos que não são estes os pontos mais ressaltados pela escrita de Lima Barreto. Na verdade, as peripécias guerreiras que representam as "salvações" aparecem como mero complemento do reprovável comportamento político dos governantes individuais e da camada dirigente que faz sua aparição nos contos. Da mesma forma, depreende-se que um governo militar pode ser considerado uma agravante da opressão social da República, tal como o autor a vivenciou, tornando o "militarismo" uma tendência a ser combatida na política brasileira. Porém, esse militarismo representaria tão-somente uma faceta a mais da estrutura sócio-política nacional, tal como se mostrava no tempo de Lima Barreto. Estrutura cujo funcionamento aparece na 
sua literatura representado necessariamente por uma dinâmica de menosprezo aos valores éticos.

Nos "Contos Argelinos", os aspectos sobre os quais o autornarrador aponta com mais ênfase constituem-se de atos amorais de diversos tipos, que geralmente deixam a própria violência do fogo e do ferro em segundo plano. Indicação eficaz disto são os títulos dos contos. Assim, o evento da "salvação" de Pernambuco, sob o nome de Al-Súgar, é contado sob o título "O juramento", que destaca um detalhe da história: o cã Ross Al-Xeiroso, ao perceber a insistência do ministro da Guerra em arrebatar-lhe o seu domínio, procura o sultão e recebe dele todas as promessas, resumidas no juramento de que até se suicidaria, caso o cã fosse esbulhado de seu governo. Na sequência, o cã acaba perdendo seus ricos domínios para o general. Mas Al-Dhudut não cumpre a palavra de se matar; segue vivendo, indiferente à expectativa de Al-Xeiroso (LIMA BARRETO: 1990, pp.237-238).

Da mesma forma, as passagens que envolvem o canato de AlBandeirah (São Paulo, terra das bandeiras, dos bandeirantes) ilustram o comportamento deplorável de suas classes altas e até de seu povo. Aquelas por sua mesquinhez e egoísmo, e este por seu orgulho insensato e sua ingenuidade. Com efeito, o canato era 0 centro da resistência ao despotismo do sultão não por sua coragem e lealdade, e sim devido à capacidade de iludir aliados e corromper adversários, em que eram hábeis suas elites. Nos contos "A firmeza de Al-Bandeirah", "O desconto" e "A solidariedade de Al-Bandeirah" (LIMA BARRETO: 1990, pp.239-244), são focalizadas as jogadas políticas dos próceres paulistas diante da ameaça de intervenção federal. Em contraponto, são ilustradas as transações políticas vigentes no período entre o governo central e a oligarquia bandeirante, bem como a atitude corrupta de membros do governo. A ironia do narrador cria o contraste entre os títulos, sugestivos de virtudes, e os verdadeiros conteúdos que nomeiam. A "firmeza" de 
Al-Bandeirah se revela na história em que, antevendo a intervenção que o governo de Al-Dhudut preparava, o canato se apresentou unido. O povo, acostumado a confiar no discurso da elite, cerrara fileiras com ela, sem notar que aquilo que ela defendia no canato eram seus próprios privilégios, negócios e riquezas particulares. Garantindo resistir até o fim, se necessário, os governantes de AlBandeirah promoveram agitações, e acabaram causando o sofrimento e até a morte dos que neles confiaram e enfrentaram a repressão do governo central. Contudo, diante da persistência deste em atacar o principado, aqueles governantes transigiram e negociaram com 0 inimigo prestes a combater, subornando um parente do grande soberano. Assim se livraram da ameaça de ataque. Quanto ao conto sobre a "solidariedade" do canato, é nele que Lima incluiu o relato da "salvação" de Hbaya, segundo o qual este principado demonstrara mais firmeza que Al-Bandeirah e resistira de armas na mão, com o resultado que já sabemos. É útil lembrar que Bahia e São Paulo haviam estado juntos no lado oposto ao da candidatura de Hermes, nas eleições para presidente. Lima Barreto acrescenta o detalhe de que, no mesmo dia em que a capital de Hbaya foi bombardeada, o irmão do sultão, dignitário subornado para obter a suspensão do ataque a Al-Bandeirah, recebia sua paga, como contara na historieta "O desconto". Esta foi a solidariedade de Al-Bandeirah para com seu aliado.

Apresentando os exemplos acima, retirados dos contos, esperamos ter ilustrado nossa análise destes textos alegóricos sobre o governo Hermes da Fonseca. Agora, antes de discutir porque Lima Barreto teria lançado mão dessa forma literária para escrever sobre os assuntos constantes nos "Contos Argelinos", faremos algumas observações acerca de aspectos do caráter da sociedade e da política da Primeira República, os quais suscitaram nele avaliações críticas contundentes, do ponto de vista ético. 
Sabe-se da postura atenta e crítica do escritor carioca diante das mudanças políticas e sociais que marcaram as décadas da passagem do século XIX para o XX no Brasil. Praticamente não se encontra aspecto social ou político brasileiro que ele não tenha trazido à baila em seus escritos e discutido sem rebuços. A República como novidade política e o desenvolvimento da sociedade burguesa estiveram constantemente sob o crivo de sua observação e de suas opiniões pouco reverentes. As injustiças, as hipocrisias e os desequilíbrios sociais, e os defeitos da organização política foram apontados e costumeiramente reprovados por ele. Não é preciso esforço para se encontrar em suas obras a crítica dos costumes e convenções sociais, aliás a tônica de sua escrita. Os deslizes éticos de pessoas e grupos forneceram assim bastante assunto em seus textos, deslizes que pareciam crescer com a expansão das relações de produção capitalistas e a intensificação de características sócioculturais pautadas pelo individualismo burguês.

A consciência dessas transformações, numa época em que elas se processavam mais aceleradamente, e a opinião negativa sobre aspectos básicos delas refletem-se na obra do escritor. Uma das tendências do seu pensamento foi a formulação, mais ou menos ligeira, mas repetida, de comparações entre o presente e o passado da nação. Embora o ambiente de desenvolvimento do mercado de trabalho livre e os discursos anunciadores de uma cidadania aberta a todos pudessem inspirar otimismo e sensação de progresso socioeconômico, o escritor, como qualquer observador minimamente atento, entendia que a cidadania ampla e o progresso estavam reservados a poucos, enquanto a marginalização e a miséria formavam o quinhão da maioria. Ele também percebia a erosão de valores sociais, éticos e até mesmo estéticos no seu tempo. Esta erosão ela via mais acentuada nas elites políticas e econômicas do país, pelas suas descrições já uma verdadeira derrocada moral. Nas 
anotações satíricas que fez acerca da Bruzundanga (outro nome para o Brasil), ele registra no capítulo "A sociedade":

É deveras difícil dizer qualquer coisa sobre a sociedade da Bruzundanga. È difícil porque lá não há verdadeiramente sociedade estável. Em geral, a gente da terra que forma a sociedade, só figura e aparece nos lugares do tom, durante muito pouco tempo. Os nomes mudam de trinta em trinta anos, no máximo.

(...)

Pode ser definida a feição geral da sociedade da Bruzundanga com a palavra - medíocre.

Vem-Ihe isto não de uma incapacidade nativa, mas do contínuo tormento de cavar dinheiro, por meio de empregos e favores governamentais, do sentimento de insegurança de sua própria situação (LIMA BARRETO: 1998, p.71).

Essa alta sociedade, afluente e carregada dos símbolos da modernidade capitalista, formava a elite republicana, cada vez mais identificada com os destinos do novo regime. Lima Barreto via nela diferenças acentuadas em relação à antiga e dispersa elite imperial, diferenças nos costumes, nas perspectivas de vida, nas ambições e provavelmente nas relações com o grosso da população e com as coisas do país. Em uma das passagens do romance "Vida e morte de M. J. Gonzaga de Sá", o protagonista leva seu amigo, o narrador da história Augusto Machado ao Teatro Lírico, ponto de encontro da nova elite, "núcleo atual de tantas ilusões". Lá, o velho funcionário Gonzaga passa em revista alguns importantes personagens ali presentes, indicando-os ao amigo com comentários que denotam a mediocridade e até a inferioridade moral de um e de outro. Trocam impressões acerca da inquietude e desconforto aparentados pelo distinto público presente, e Gonzaga afirma que isto se devia ao fato de eles temerem o futuro. E acrescenta, provocando um diálogo com Machado nestes termos: 
- Vocês, os moços, fizeram mal em destronar os antigos. Apesar de tudo, nós nos entenderíamos afinal. Vínhamos sofrendo juntos, vínhamos combatendo juntos, às vezes até nos amamos entenderíamo-nos por fim. Estes de agora...

- Nada impede que nos entendamos afinal com estes, também!

- Qual! São estrangeiros, novos no país, ferragistas e agiotas enriquecidos, gente nova... Vocês estão separados deles por quase quatrocentos anos de história, que eles não conhecem nem a sentem nas suas células (...) vocês arranjaram novos dominadores, com os quais vocês não se poderão entender nunca; e expulsaram os antigos com os quais, certamente, se viriam a entender um dia. Erraram, e profundamente.

Machado observa e pensa, e sente-se de repente diante de um "mundo hostil'. Compara a si próprio com aquela gente e considera que a posição em que ela estava, afinal de contas, era seu prêmio. "Tinham saltado por cima de todas as conveniências, por cima de todos os preceitos morais - tiveram coragem $(\ldots)^{\prime \prime}$. Mais tarde, Gonzaga volta atrás de considerar aquele público tão diverso dos "antigos", embora afirme que estes "eram mais nossos parentes" (LIMA BARRETO: 1961, pp.156-159).

No catálogo de defeitos dessa "sociedade" que dava o tom no país, junto àqueles propriamente éticos, análogos aos condenados no Decálogo, Lima Barreto inclui os defeitos de gosto artístico e cultural, e a própria falta de sensibilidade para com as belezas, os valores e as potencialidades do país. Exemplos não faltam, nas obras do escritor.

Tais deficiências são mais ressaltadas quando são estabelecidos pontos de comparação com os tempos da Monarquia. O autor manifesta suas simpatias por diversos aspectos desse passado político e social brasileiro, tomando posição favorável em relação a tradições, costumes e atitudes que acreditava mais valorizados nessa época anterior. 
Uma citação curiosa do autor, que embora fazendo parte de uma coleção de textos satíricos, dá um golpe de vista sobre o assunto aqui tratado, testemunhando ao mesmo tempo sua simpatia por um passado possivelmente idealizado, e a ojeriza que tinha à insensibilidade estética, e de forma mais ampla, cultural da elite de seu tempo. Apesar da extensão, vale transcrevê-la. No capítulo "As letras na Bruzundanga", o narrador descreve como em todas as épocas anteriores os homens dedicados às letras tinham em alta conta o seu ofício, o qual encaravam como uma verdadeira missão sagrada, ligada ao divino. Esses seres especiais também gozavam de apreço e até de veneração por parte dos elementos das classes altas nas sociedades em que viviam. O profundo senso do valor de sua atividade os impediria de rebaixar a sua arte, a que preço fosse, a mero passatempo dos ricos e poderosos do tempo. A tarefa de prover esse passatempo ficaria reservada aos bobos da corte e assemelhados. Mesmo se um nobre por acaso tivesse um poeta a seu serviço, a este escritor estava reservada tão-somente a celebração literária dos grandes acontecimentos da sociedade a que o seu senhor se ligasse; função estrita que, como outras prerrogativas dos "homens de pena", eram aceitas respeitosamente como decorrência do orgulho profissional de tais criaturas. Dito isto, o narrador passa a considerar que também no país da Bruzundanga as coisas ocorriam assim, "até bem pouco". Nas suas palavras:

A sua nobreza territorial e agrícola estimava muito, a seu jeito, os homens de inteligência, sobremodo os poetas, aos quais ela perdoava todos os vícios e defeitos. Essa fidalguia à roceira daquele país era assim semelhante aos nossos "fazendeiros", antes da lei de 13 de maio; e poeta, ou mesmo poetastro, que aportasse nas suas fazendas, que lá são chamadas - "ampliúdas" - tinha casa, comida, roupa nova, quando dela precisasse, e lavada toda a semana, podendo demorar-se no latifúndio o tempo que quisesse, e fazendo o que bem lhe parecesse, desde que nada tentasse contra a 
decência e a honra da família. Por agradecimento, então, em dia festivo da família ou da religião, ao jantar cerimonioso e votivo, o vate recitava uma poesia inédita, alusiva ou não ao ato, e tomava uma grande e alegre carraspana. (LIMA BARRETO: 1998, p.116)

Depois de descrever tão idílica situação dos escritores de outrora, incluindo os da Bruzundanga, que como é sabido é mesmo o Brasil, o cronista apresenta uma reversão deste quadro, tão radical quanto ainda próxima no tempo:

Recentemente, na Bruzundanga, uma revolução social e, logo em seguida, uma política, deslocaram essa boa gente da fortuna, e muitos deles, até, dos seus domínios, que vieram a cair nas mãos de aventureiros recentemente chegados à terra ou, quando nascidos nela, eram de primeira geração, descendendo diretamente de imigrantes recentes cujo único pensamento era fazer fortuna do pé para a mão, cheios de uma avidez monetária e inescrupulosa que transmitiram decuplicada aos filhos, e logo os lindos costumes de antiga nobreza agrária se perderam. Os poetas foram postos à margem e não tiveram mais nem consideração nem desprezo. Era como se não existissem, como se fosse possível isso, seja em sociedade humana, fora de qualquer grau de civilização que ela esteja." (LIMA BARRETO: 1998, pp.116-7)

Podemos identificar na "revolução social" a culminância do processo de extinção da escravatura no nosso país, e na "revolução política", tão próxima da anterior (1888-1889), a implantação do regime republicano. Vemos que, nas considerações éticas de Lima Barreto, a estética revestia-se de um valor decisivo.

Por conseguinte, diante de uma elite pautada pela escassa sensibilidade ética e até estética, não seria de admirar que ela fosse capaz de sustentar e gerir um regime político senão feito, pelo menos adaptado à sua imagem e semelhança. A República oligárquica, liberal no sentido de não oferecer entraves à acumulação capitalista 
de seus beneficiários e de tutelar a exploração do trabalho e marginalização das classes subalternas, foi matéria volumosa de muitas das críticas mais ferinas do autor.

Nas esferas da política, menosprezados os possíveis projetos partidários para a administração do país e violadas repetidamente as regras mínimas de lealdade e respeito à coisa pública, tudo se resumia à luta pelo poder e a riqueza. Opinando sobre o jogo político oficial, Lima Barreto escrevia, pela pena de Bogoloff:

Mais atroz e feroz esse jogo aparecia à vista da temporariedade dos cargos e da falta de uma base fixa e forte em que os detentores atuais se apoiassem ou pela bajulação, ou pelo talento, ou pelo sangue, como aconteceria se estivéssemos sob um Império ou numa monarquia qualquer [grifo nosso] (LIMA BARRETO: 2001, pp.130-1).

Provavelmente o principal fator para esta sofreguidão de obter o máximo de benefício material e de ascensão social, conforme a opinião do escritor, seja constituído pela sensação de precariedade trazida pelas mudanças sociais no Brasil. Vivia-se num quadro socioeconômico e político sensivelmente móvel, cuja velocidade de alterações induzia ao ceticismo para com a firmeza dos parâmetros éticos, entre outros, até então encarados com mais confiança. Talvez mais que o restante da sociedade, as elites brasileiras percebiam e vivenciavam isto. Daí o desassossego que Lima Barreto detectava no agir dessa gente, conforme vista por seus personagens, como no seu conto "Uma noite no Lírico":

Saímos para o saguão e eu me pus a ver todos aqueles homens e mulheres tão maldosamente catalogados pelo meu amigo. Notei-lhes as feições transtornadas, o tormento do futuro, a certeza da instabilidade de suas posições. $V i$ todos eles a arrombarem portas, arcas, sôfregos, febris, preocupados por não fazer bulha, a correr à menor que fosse... (LIMA BARRETO: 2001b, p.155) 
A respeito da intencionalidade de Lima Barreto ao utilizar a linguagem alegórica nos "Contos Argelinos", descartamos a hipótese referida antes, segundo a qual temores reforçados pela situação profissional do escritor teriam influído de forma decisiva na escolha dessa forma literária. Mesmo exercendo o cargo de amanuense justamente no Ministério da Guerra, o que o tornava alvo mais próximo e visível para alguma represália das figuras cujos atos condenáveis abordava, revestir a narrativa crua com as distorções da caricatura e da alegoria não nos parece um procedimento feito com intuito de ocultar as fontes do assunto dos contos. Duas considerações são levadas em conta para sustentar esta opinião: as alegorias dos contos pouco escondem da verdadeira identidade dos personagens históricos retratados e da veracidade básica dos fatos narrados, que podem ser percebidos sem grandes dificuldades, ainda mais se o objetivo do autor fosse a recepção da mensagem dos textos fossem os leitores do tempo; fatos e personagens dos "Contos Argelinos" aparecem na ficção de Lima Barreto em outras obras, na mesma situação de fácil identificação, às vezes em referências praticamente explícitas.

Pensamos que, diante da profusão de acontecimentos merecedores de tratamento literário e reflexão crítica, como foram os dos quatro anos do turbulento governo Hermes da Fonseca, o procedimento de recorrer à alegoria e à sátira para descrevê-los terá parecido ao escritor passível de atingir com mais profundidade o senso crítico dos leitores. Para Lima, a utilização destas formas não era estranha ao seu conhecimento nem à sua experiência, leitor que era de Swift e outros mestres da sátira e da alegoria. Mesmo envolta em circunstâncias ficcionais alteradas, a projeção de fatos verídicos em lugares distantes e exóticos, tão distantes no espaço e na vivência cultural que parecem ao leitor pertencer a um universo onírico, permite criar um efeito especular. Os fatos próximos e envolventes que parecem fugidios a um olhar atento e racional, 
quando mostrados a uma distância elaborada artificiosamente pela ficção, podem ser vistos em uma perspectiva mais abrangente e objetiva. Numa ponte onde se pode circular entre uma ética abstrata e uma necessidade concreta de justiça. A busca deste efeito, no entender de Lima Barreto, era uma tarefa a serviço da arte, cujo objetivo seria dizer o que os simples fatos não dizem (BARBOSA: 1981, p.237).

Portanto, na falta quase institucionalizada de posturas éticas que Lima Barreto enxergou na sociedade de seu tempo e na orientação do regime republicano no Brasil, a eclosão de episódios de grande violência, tal como aconteceram alguns na gestão do presidente Hermes, não destoam do desequilíbrio e da precariedade institucional presentes na sociedade e na política vigente. Embora trazendo uma carga dramática forte ao ser observada, a violência militar aparece como uma decorrência da violência congênita de um regime pautado, entre outras coisas, pelo desrespeito aos interesses das classes subalternas, como se poderia esperar de qualquer regime político mantenedor do domínio de uma classe em prejuízo do restante da sociedade; como qualquer regime sob a égide do capitalismo. E que ainda não pudera desenvolver, até internamente, mecanismos de limitação ou disfarce do caráter antiético de sua dominação.

\section{REFERÊNCIAS :}

BARBOSA, Francisco de Assis. A vida de Lima Barreto. 6a. Ed. Rio de Janeiro: José Olympio, 1981.

CARVALHO, José Murilo de. Os bestializados. $3^{a}$. Ed. São Paulo: Companhia das Letras, 1991.

LIMA BARRetO, A. H. Aventuras do Dr. Bogoloff. Rio de Janeiro: Expressão e Cultura, 2001a.

. Os Bruzundangas. São Paulo: Ática, 1998. 
. Contos reunidos. Rio de Janeiro/Belo Horizonte: Garnier, 1990. 2001b.

. Histórias e sonhos. Rio de Janeiro: Expressão e Cultura, 2011.

. Triste fim de Policarpo Quaresma. São Paulo: Penguim, . Vida e morte de M. J. Gonzaga de Sá. $2^{a}$. Ed. São Paulo: Brasiliense, 1961.

ROSSO, Mauro. Lima Barreto e a política: os "Contos argelinos" e outros textos recuperados. Rio de Janeiro: Ed. PUC-Rio; São Paulo: Ed. Loyola, 2010.

SILVA, Hélio e CARNEIRO, Maria C. R. Luta pela democracia. São Paulo: Ed. Três, 1998.

SOUZA, Maria do Carmo C. de. "O processo político-partidário na Primeira República". In: MOTA, Carlos G. (org.). Brasil em perspectiva. $8^{a}$. Ed. Rio de Janeiro/São Paulo: Difel, 1977. 